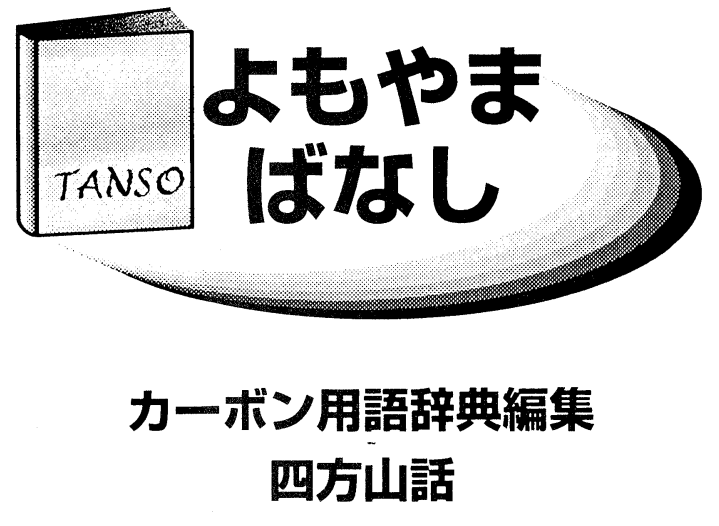

カーボン用語辞典編集幹事 夏目 勇, 小林和夫, 木村修七

\section{第九話 カーボン産業の技術用語}

はじめに

用語辞典の編集にあたり，学術用語たけげなく炭素業界内 で使用されている技術関係用語も組み入れることとなり, 用 語項目の選択を始めて次のようないろいろな問題が持ちあが った。それらは, 標準的でかつ適切な日本語と英語の用語や 表現の問題, 大学や公的機関の研究者とメーカー技術者との 間で用語とその語意に違いがあること, さらに同業者間でも 用語に統一がないものがあることなどである。ここにその幾 つかの例を挙げてみる。編集段階ではその一つを選択せざる を得なかった。今後広く関係分野で用語統一も課題とされる ことを訴えたい。

\section{1. 産業界内の用語の違い}

産業界で使用されている技術用語には, 異業種間だけでな く同一業種間でも各社の歴史を反映して違いがある。その例 を‘kneading’について同業種ならびに異業種間の用語の違 いを挙げてみる。

一般の炭素材を成形体から作るときの, 原料フィラーとバイ ンダーを均一分散する単位操作は, 英語の表記では ‘kneading’ であり, 単純な分散を目的とする「混合」mixing とは使い分け られている。これについて国内炭素材メーカー各社では, kneadingの日本語には「混捏(こんねつ)」「捏合」「混練」「捏和 (ねっか)」などの歴史的な用語が用いられており,この順に使 用呼称が多いようである。粘稠な原料に剪断力をかける語意 の当用漢字にはない ‘捏る (こねる)’の「捏」が, また同義とし て ‘練る’ “練り达む” 表意の「練」が使用されてきたと思われ るが, 本辞典の編集では統一して「混練」を採用した。

‘kneading’ 相当の用語は炭素材以外の分野では, ゴム工業 およびプラスチックス工業では「混練り(こんねり)」が標準 とされているようで, これらを需要先とするカーボンブラッ
ク分野でもこの用㖖が使用されている。また粉体上涑では 「混練」が, 割業分野では「捏練」も一部で使用されているよ うに䦌く。

\section{2. 学術用語と産業界の用語との違い \\ 2.1 炭素質と黒鉛質}

炭素材工業では製品および中間品の材筫の呼称には「質」 を付けて，「桨素質」「黑鉛質」との用語が恒常的に使用され， 取引などでも用いられる。この場合は一般に, 非黒鉛質炭素 を原料とした黒鉛化処理前までの熱処理物を「炭素質」と呼 び, 黑鉛化処理され黑鉛が主体となった材料,ないしは黑鉛原 料を主体として形成された材料を「黒鉛質」と娥んでいる。 また一方で, 総合的呼称として「炭素材」は寸べての炭素啠材, 黒鉛質材を含める習慣ともなっている。厳密に言えば,この 四方山話第二話 (炭素, 2000, [No.194] 311) の論議のように, ここでの炭素質は「非黒鉛質」, 黒鉛質材は「黒鉛質炭素材」と 呼ぶべきであろうが, 業界では長年の習慣で上のような呼称 が主流である。他方，黑鉛化処理されたものでも黑鉛質とな っていない材料については統一された呼び名はないと思う。

\section{$2.2\lceil$ 焼成」と「熱処理」}

熱処理の用語について, 炭素材工業では関連する技術分野 のセラミックスなど,および, 学術分野用語などと同じ「焼 成」を使用するが, 用語の温度範囲についての認識に唁があ る。炭素材工業分野での語意は, 黒鉛化処理温度未満の揮発 成分の大部分を除く温度までを焼成温度の上限としている。 すなわち焼成に続く熱処理が黒鉛化処理になる。セラミック ス分野ではこの炭素材工業の「焼成」温度以上の高温処理も 含めて焼成であり，学術用語では黒鉛化までをも焼成熱処理 に含められるところに差がある。

炭素材工業の一部ではこの焼成熱処理に「仮焼」の語が使 用されることがあるが，これは事前熱処理を指す語であるの で適切でない。この語の使用は引き続いて黒鉛化が行われる ときの前処理工程との意識の表われであろう。

また熱処理関連の用語「ばい (焙) 焼」は, 本辞典では該当す る英語名をCalcinationとしているが, セラミックス等の分野で はbaking も使われている。逆に金属分野などではbakingは揮 発成分の除去処理の加熱を指す用語として使われている。

\section{3. 日本語名と英語名}

日本語名と英語名について見てみると, 使用語の実態には 歴史的な背景による差もあり,このため上に述べた表記のほ か語意も異なる表現不一致のケースもある。新しい工業プロ セスが出てきてその用語も統一されていないものがあるが, 旧来の用語でも学術用語と業界用語の違いもある。これらの 例を次に挙げてみる。

\subsection{LWG炉 (直接通電黒鉛化炉, 直列黑鉛化炉)}

量産大型材の黒鉛化方式には, 従来からのAcheson型炬に 対して, 近年, 高い生産性と省エネ方式のLWG炉が一般的と なっている。現在の一般通用語は「LWG」で, 日本語名も直 
挍通電黑鉛化炉，直列黑鉛化炉等とさまざまで統一されてい ない様である。この語はLengthwise graphitizing furnace (本辞 典t.p.30, p.437のLengthwidthは編集の䛊り)の略であるが，コ 一ロッパの電気加熱の刊行資料1)ではUnifilar graphitizing furnace (縦列黑鉛化炉) なる用望が使われており, 本辞典に は再英語名を表示した。世界的にどちらも通用しているのか 識者のご教示を得たい。

\section{2 膨張黒鉛}

膨張黑鉛の学術名はExfoliated graphite であり, 黑鉛層間化 合物を急速加熱処理したものである。産業界ではこの中間商 品は著しい嵩高のため脵張処理以前の酸処理物の段階で取引 されている。わが国では膨張前の阔品を膨張黒鉛Expandable graphite, 膨張後の商品を膨張化黑鉛Expanded graphite と区分 して称している。ヨーロッパの産業界でもExpanded graphite も使用されている!模様なので, 本辞典にはこのExpanded graphiteも記載した。

\section{4. 商品名と商標問題}

\section{1 商品名の汎用語化}

技術開発により製品化された先行商品は币場で優先的に利 用され，その商品名は当該商品の代表として広く認知される。 炭素製品の例では, わが国で精力的に開発, 商品化され広く利 用されているガラス状カーボンがあり, その商品名 GLASSY CARBONグラッシーカーボンは一般名の Glasslike carbon と 同等に使用されている。

また米国で開発され商品化されたものに，炭素材を超高温 hot-pressingにより基材の気孔をつぶして欠陷を制御し, 構成 微結晶の配向も促進させる技術による製品は商品名Recrystallized graphite 再結晶黒鉛と名付けられた。これは本来 の「再結晶」化ではない (本辞典p.127参照) が,一般名とし
て使われている。

そのほかに, 炭素材の気孔を熱硬化樹脂で含浸して不浸透化 し, 腐食性流体の処理プロセス設備に利用されてきた材料・機 器の商品名のKARBATEカーベートも一般名化している。本 辞典では一般名化したと見られる用語は項目として採用した。

\section{2 商標問題}

最近一般名ないしは固有名詞の英語名やその略号を商標登 録して権利化する風潮がある。類似語の例では, かつて上述 のGlassy carbonは先行メーカーが開発したGlasslike carbonの 製品に命名して片仮名および英語名で登録した ${ }^{2)}$ 。方, メソ カーボンMesocarbonのマイクロビーズmicrobeadsを先行開発 工業化したメーカーは, 自己の固有名称の略号KMFCで商標 登録したが3), 他の一社はこれの英語名の略号ともいうべき MCMBを商標登録している4)。また気相成長岑素綫維Vaporgrown carbon fiber の略号VGCFも商標登録されている5。

MCMBあるいはVGCFなる用語はその缐品を意味するこ とになり，一般研究者が中立の立烫でこの用語をその種類の 一般製品について使用するときは，その特定の商品を指すこ とにもなり不都合である。一般名称の略号をもつて権利化す ることは好ましくないと考える。

(文責 夏目 勇)

\section{文 献}

1) Ed. Uion of International Elecroheating, "Electromagnetic Induction and Electric Conduction in Industry"; CFE, (1997) 205.

2) 商標登録第2367687号 1991年3月, 出願 1989年7月.

3）商標登録第1931227号 1987年2月, 出願1984年11月.

4）商標登録第4059699号 1997年9月, 出願1996年3月.

5）商標登録第2329840号 1991年8月,出願1989年2月. 